\title{
Carbon sequestration in hedgerow biomass and soil in the temperate climate zone
}

\author{
Sophie Drexler ${ }^{1} \cdot$ Andreas Gensior $^{1} \cdot$ Axel Don ${ }^{1}$ \\ Received: 10 June 2020 / Accepted: 29 May 2021 / Published online: 10 July 2021 \\ (C) The Author(s) 2021
}

\begin{abstract}
Hedgerows are a traditional form of agroforestry in the temperate climate zone. The establishment of hedgerows may be a promising strategy to promote carbon (C) sinks for climate change mitigation. We therefore conducted a meta-analysis compiling data from 83 sites on soil organic carbon (SOC) stocks beneath hedgerows in comparison with adjacent croplands and grasslands, plus biomass data from 64 hedgerows. On average $( \pm S D)$, the establishment of hedgerows on cropland increased SOC stocks by $32 \pm 23 \%$. No significant differences were found between the SOC stocks of hedgerows and those of grassland. The average above-ground biomass stock was $47 \pm 29 \mathrm{Mg} \mathrm{Cha}^{-1}$. Only one study reported measurements of below-ground biomass stocks and root/shoot ratios. Based on these measurements, an average below-ground biomass stock of $44 \pm 28 \mathrm{Mg} \mathrm{C}^{-1}$ was estimated, but with high uncertainty. In total, hedgerows were estimated to store $104 \pm 42 \mathrm{Mg}$ ha $^{-1}$ more $\mathrm{C}$ than croplands, with biomass contributing $84 \%\left(87 \pm 40 \mathrm{Mg} \mathrm{Cha}^{-1}\right)$ and soil $16 \%\left(17 \pm 12 \mathrm{Mg} \mathrm{Cha}^{-1}\right)$ to this amount. Total $\mathrm{C}$ sequestration with the establishment of hedgerows on cropland could be between 2.1 and $5.2 \mathrm{Mg} \mathrm{ha}^{-1}$ year $^{-1}$ for a period of 50 and 20 years, respectively. Our results indicate that $\mathrm{C}$ stocks in hedgerows are on average comparable to estimates for forests. The establishment of hedgerows, especially on cropland, can therefore be an effective option for $\mathrm{C}$ sequestration in agricultural landscapes while enhancing biodiversity and soil protection.
\end{abstract}

Keywords Carbon storage $\cdot$ Soil organic matter $\cdot$ Agroforestry $\cdot$ Climate change mitigation $\cdot$ Review $\cdot$ Climate-smart agriculture

\section{Introduction}

Global efforts are being made to combat climate change. All mitigation scenarios rely not only on reducing greenhouse gas emissions, but also on having negative emissions (Fuss et al.

This article is part of the Topical Collection on Regional management practices with positive effects on soil carbon to meet the goals of the 4 p1000 initiative

Communicated by Cornelia Rumpel and Claire Chenu and accepted by Topical Collection Chief Editor Christopher Reyer

Axel Don

axel.don@thuenen.de

Sophie Drexler

sophie.drexler@thuenen.de

Andreas Gensior

andreas.gensior@thuenen.de

1 Thünen Institute of Climate-Smart Agriculture, Bundesallee 65, 38116 Braunschweig, Germany
2014). Land-use, land-use change and forestry activities, which are included in greenhouse gas inventories, offer the possibility of negative emissions by sequestering carbon (C) (Schlamadinger et al. 2007). Biological C sequestration is defined as the net removal of carbon dioxide $\left(\mathrm{CO}_{2}\right)$ from the atmosphere and storage in long-term $\mathrm{C}$ pools, including above-ground and below-ground biomass, deadwood and litter and the relatively stable pool of soil organic carbon (SOC) (IPCC 2006c; Lal 2008). SOC sequestration in particular is seen as part of the solution to mitigate climate change (Lal 2004). With around $2400 \mathrm{Pg} \mathrm{C}$ stored in the upper $2 \mathrm{~m}$ of soils worldwide, SOC is the largest terrestrial C pool (Batjes 2014). Thus, even a small SOC increase can play a significant role in the global $\mathrm{C}$ cycle. This has recently been promoted by the " 4 per 1000" initiative, which underlines the importance of the soil $\mathrm{C}$ pool. The theoretical calculation of a global annual increase in SOC of $4 \%$ is equal to the total annual anthropogenic $\mathrm{CO}_{2}$ emissions (Minasny et al. 2017).

The implementation of agroforestry is a generally accepted $\mathrm{C}$ sequestration option and is acknowledged as an afforestation activity under the United Nations Framework Convention on 
Climate Change (UNFCCC) (Albrecht and Kandji 2003; Montagini and Nair 2004; Pandey 2002). In agroforestry systems, woody perennials and crops and/or animals are combined within the same site for a variety of benefits (Nair et al. 2009; Schoeneberger 2008). The benefits of agroforestry systems depend on the context, e.g. the type of agroforestry or the geographical region. Overall, however, agroforestry has a positive effect on the ecosystem, such as increasing soil fertility and biodiversity and reducing soil erosion (Torralba 2016). Agroforestry systems store on average more $\mathrm{C}$ in the aboveand below-ground biomass and in the soil than grasslands or croplands (Chatterjee et al. 2018; De Stefano and Jacobson 2018). The higher plant biomass of agroforestry systems is perennial and has a longer rotation compared with crops that are harvested annually. During growth, the biomass captures and stores $\mathrm{CO}_{2}$ and acts as a semi-permanent, non-forest woody $\mathrm{C}$ sink. The periodically harvested biomass can be used as an energy source, substituting fossil fuels and offsetting their $\mathrm{C}$ emissions (Gruenewald et al. 2007; Holzmueller and Jose 2012; Kürsten 2000). The main reasons for increased SOC stocks in agroforestry systems are increased $\mathrm{C}$ inputs from above-ground litter and increased below-ground $\mathrm{C}$ inputs, especially deep soil $\mathrm{C}$ inputs from trees with extensive root systems (Cardinael et al. 2018a; Oelbermann et al. 2005; Sierra and Nygren 2005). Moreover, increased SOC stocks in agroforestry systems are attributed to altered microclimatic conditions and less soil disturbance (Lorenz and Lal 2014). In a recent quantitative review, Feliciano et al. (2018) showed that the potential for $\mathrm{C}$ sequestration and storage in agroforestry systems differs considerably depending on the type of agroforestry, climate, time since land-use change and the previous land-use. The average $\mathrm{C}$ sequestration rate after agroforestry establishment ranged from 0.5 to $13.0 \mathrm{Mg} \mathrm{C} \mathrm{ha}{ }^{-1}$ year $^{-1}$ in the above-ground biomass and from -4.0 to $6.7 \mathrm{Mg} \mathrm{C}^{-1}$ year $^{-1}$ in the soil. In another global meta-analysis, Ma et al. (2020) found that in particular tree species richness influences biomass $\mathrm{C}$ storage of agroforestry systems and accelerates the $\mathrm{C}$ sequestration process, emphasising that besides site properties, the type of agroforestry needs to be taken into account when considering SOC sequestration potential.

A traditional type of agroforestry is hedgerows. Hedgerows are commonly found in Western Europe, especially in Great Britain and France, but are distributed all over the temperate climate zone (Burel 1996). Hedgerows vary widely and can be classified based on their dominant species (e.g. hawthorn), their function (e.g. windbreaks), their shape (e.g. hedge-banks) or their origin type (planted or remnant), and they differ in their length, width, height, management, species composition and age (Forman and Baudry 1984; Kühne et al. 2000; Weber 2008). There is no common definition of the term hedgerow (Haddaway et al. 2018), and shelterbelts or windbreaks are often also considered hedgerows (Mayrinck et al. 2019). Moreover, local names such as "bocage" in France or "Knick" in Germany are used to describe the type of vegetation or landscape of hedgerows. Particularly with regard to their ecological function, a differentiation should be made between hedgerows and other linear agroforestry types or field margins consisting of only one or more rows of trees. The positive effects of hedgerows can only be fully achieved if they are adequately managed and present in their traditional form. This includes a dense woody structure with shrubs. The structure of hedgerows influences e.g. the wind-erosion control provided (Bird et al. 2007) and has effects on biodiversity. Hannon and Sisk (2009) showed that the dense shrub layer present only in mature hedgerows is a preferred habitat for native bees in Arizona. Dunn et al. (2016) found that farmland songbirds prefer hedgerows with high vegetation cover for nest site selection and that hedgerow management affects songbird survival because nest predators are favoured by patchy, open hedgerows. Based on Burel (1996), Baudry et al. (2000) and Van Vooren et al. (2017), we thus define hedgerows here as managed, linear structures composed of perennial shrubs or shrubs and trees established adjacent to agricultural fields. Shelterbelts and windbreaks were included if they contained not only trees but also a proportion of shrubs.

As with other types of agroforestry, hedgerows are thought to store and sequester substantial amounts of $\mathrm{C}$ in their biomass and soil. The establishment of hedgerows as a management practice to sequester SOC is mentioned within the scope of the "4 per 1000" initiative (Minasny et al. 2017), and hedgerows are an explicitly listed agroforestry practice in the IPCC guidelines on National Greenhouse Gas Inventories (IPCC 2006c). Recently $\mathrm{C}$ storage coefficients were defined specifically for hedgerows for different climate zones (Cardinael et al. 2018b) and included in the 2019 Refinement to the 2006 IPCC Guidelines for National Greenhouse Gas Inventories (IPCC 2019a). In Germany, hedgerows become increasingly relevant in the context of climate change mitigation, as they are mentioned as a measure for $\mathrm{C}$ sequestration on cropland in the German government's recently presented Climate Action Programme 2030 (Federal Government 2019). There has been a general decline in hedgerows in most regions of the world for more than 70 years, with negative effects on biodiversity and soils (Amichev et al. 2020; Barr and Gillespie 2000; Poschlod and Braun-Reichert 2017). Thus, there is great potential to establish new hedgerows to compensate for these historical losses. Aertsens et al. (2013) estimated that the SOC sequestration potential in the EU-27 may be 18 million $\mathrm{Mg} \mathrm{C}$ year $^{-1}$ for the establishment of $100 \mathrm{~m}$ hedgerow per hectare of agricultural land. This estimate was based on a study conducted in a longestablished hedgerow network in France (Walter et al. 2003) and calculations by Arrouays et al. (2002). Arrouays et al. (2002) estimated a SOC sequestration rate of $0.1 \pm 0.05 \mathrm{Mg} \mathrm{C}$ $\mathrm{ha}^{-1}$ year $^{-1}$ for the establishment of $100 \mathrm{~m}$ hedgerow per hectare of agricultural land, and a transition time between equilibrium SOC values of 20 years. However, the $\mathrm{C}$ stocks within the sampled hedgerow network showed a high spatial variability, 
and as the sampled hedgerows were perpendicular to the slope, translocation effects could have added uncertainty to the estimation of SOC stocks. Falloon et al. (2004) estimated a C sequestration potential for field margins of between 0.1 and 2.4 $\%$ of the $1990 \mathrm{UK} \mathrm{CO}_{2}$ emissions, depending on the field margin type and width. For hedgerows, Falloon et al. (2004) took data from agricultural set-aside land representative of the $\mathrm{C}$ sequestration in hedgerow biomass and assumed SOC sequestration to be intermediate between grass margins and tree strips.

The potential of hedgerows to mitigate climate change seems substantial. However, comprehensive and quantitative overviews comprising both soil and biomass $\mathrm{C}$ in traditional hedgerow ecosystems in the temperate climate region are scarce. Previous estimates were based on only a few studies with variable data and no clear definition of hedgerow, or only having other types of vegetation representing hedgerows. This hampers not only the reporting of hedgerow sink activities in national greenhouse gas inventories, but also the assessment and resulting promotion of hedgerows within the context of climate change mitigation. The aim of this meta-analysis and review was therefore to derive comprehensive estimates of $\mathrm{C}$ stocks in both soils and biomass of hedgerows. On the basis of this analysis, we assessed the $\mathrm{C}$ sequestration potential from the establishment of new hedgerows.

\section{Material and methods}

\section{Soil organic carbon stocks}

\section{Data collection}

In order to quantify SOC stocks and estimate the SOC sequestration potential of hedgerows, we carried out a literature survey based on the ISI Web of Science database, applying the following search string: (hedge* OR bocage OR "field margin\$” OR shelter\$belt OR wind\$break) AND (carbon OR "*organic* *matter*" OR humus) AND soil. The reference lists of the obtained articles were also searched for eligible studies. The literature search was updated until May 2020 without date restrictions.

All the identified studies were screened for reported SOC contents or stocks in hedgerow soils. Only studies with a paired-plot design, in which adjacent agricultural fields were sampled as a control, were included. We looked for original studies with measured data; model studies were not considered. To be included, the control plot had to have a comparable soil type, especially a comparable texture, with that of the hedgerow plot. Another study selection criterion was compliance with our definition of a hedgerow. To obtain a complete picture of all studies dealing with hedgerows, we included different types of field margins in our search term. Studies analysing other types of field margins, e.g. windbreaks consisting of one tree line and no shrubs or field margins with mainly herbaceous vegetation, were excluded. Our analysis was restricted to the temperate climate zone with a mean annual temperature (MAT) of between 0 and $18^{\circ} \mathrm{C}$, according to the IPCC definition of temperate climate (IPCC, 2019b).

From the selected articles, we compiled data on SOC contents, SOC stocks, bulk densities, corresponding standard deviations $(S D)$ and sample sizes $(n)$ for each experiment consisting of a hedgerow plot and an adjacent agricultural field. When a transect perpendicular to the hedgerow was sampled, we chose the furthest subplot as the control. For graphically presented data, authors were contacted to provide data, or alternatively data were extracted using WebPlotDigitizer (Rohatgi 2019). When only standard errors $(S E)$ were given, standard deviations were calculated as follows: $S D=S E \times V_{n}$. If standard deviations were missing, averaged standard deviations of all other studies with the same land-use and unit (SOC content or stock) were imputed. SOC contents or stocks were extracted for all available sampling depths. In the case of more than one sampled depth increment, SOC stocks and corresponding variances were summed over all continuous sampling depths. SOC contents were averaged over all continuous sampling depths. Furthermore, we compiled data on soil texture, mean annual precipitation (MAP) and mean annual temperature (MAT) as potential explanatory variables. When information on MAP and MAT was missing, we filled the values with data from weatherbase.com, selecting the closest weather station.

\section{Meta-analysis}

The difference in SOC between the hedgerow soils and the soils of adjacent agricultural fields was studied through metaanalysis. For the quantification of $\mathrm{C}$ storage in the context of climate change mitigation, SOC stocks are preferentially selected. We therefore used SOC stocks $\left(\mathrm{Mg} \mathrm{C} \mathrm{ha}^{-1}\right)$ for comparisons when reported, while SOC contents $\left(\mathrm{g} \mathrm{C} \mathrm{kg} \mathrm{soil}^{-1}\right.$ ) were used in the remaining cases. For the conversion from SOC contents to SOC stocks, bulk density values are required. For our dataset, bulk densities were only given in two out of nine studies (measured for the same depth increment as SOC content). Therefore, it was not possible to derive reasonable bulk densities from the existing dataset and to convert SOC contents into SOC stocks. For studies with reported SOC stocks, we used mass-corrected SOC stocks where possible (two out of nine studies). For the comparison of SOC stocks of different land-uses with different bulk densities, it is necessary to compare equivalent soil masses to investigate absolute changes in SOC (Ellert and Bettany 1995). However, if only one depth increment is sampled, response ratios of SOC stocks with mass correction are the same as response ratios of SOC contents. This was the case for four studies. 
For the meta-analysis, we chose the response ratio (RR) as effect size. The RR quantifies the proportionate difference between a treatment mean $\left(\mathrm{X}_{\mathrm{t}}\right)$ and a control mean $\left(\mathrm{X}_{\mathrm{c}}\right)$ and is generally log-transformed prior to meta-analysis in order to linearise and normalise the raw ratios (Hedges et al. 1999). Unique effect sizes with corresponding $95 \%$ Wald-type confidence intervals were calculated for all studies as follows: $\ln$ $(R R)=\ln \left(X_{t}\right)-\ln \left(X_{c}\right)$. When more than one comparison between a hedgerow soil and an adjacent agricultural field was given, effect sizes were calculated for each individual pairedplot comparison. Overall effect sizes were derived for the subgroups "cropland control" and "grassland control". Both subgroups showed considerable heterogeneity between the studies, tested with Cochran's Q-test and $\mathrm{I}^{2}$ statistics (Higgins and Thompson 2002). Correspondingly, we applied a random effects model to calculate the overall effect sizes (Borenstein et al. 2010). The individual effect sizes were therefore weighted by the inverse of their variance (Borenstein et al. 2010). Lastly, all response ratios were back-transformed into percentages to aid interpretation. Analyses were performed with the metafor package (Viechtbauer 2010) in R version 3.5.3 (R Core Team 2019).

\section{Biomass carbon stocks}

Analogously to the literature survey on SOC, we compiled data on the biomass $\mathrm{C}$ stocks of hedgerows using the following search string until May 2020 without date restrictions: hedge* OR bocage OR "field margin\$” OR shelter\$belt OR wind\$break AND biomass. Furthermore, we included own, unpublished data on biomass measurements from 49 hedgerows in Germany. The material and methods of this data and the raw data can be found in the supplementary material (Online Resource, Table S.1). The accurate and precise estimation of $\mathrm{C}$ storage in biomass requires destructive sampling, excavation of the root systems and drying and weighing of the biomass (Vashum and Jayakumar 2012). Since this procedure is very time-consuming, biomass data from destructive sampling are often limited, and allometric equations are used to derive biomass estimates. Allometric equations use easy measurable factors, such as diameter at breast height, to estimate above-ground biomass. Estimates based on allometric equations can be as accurate as destructive sampling techniques, but only when appropriate coefficients for the site and species are used (Dittmann et al. 2017). To our knowledge, there are no such adapted functions for hedgerows in the temperate climate zone. Thus, we excluded biomass data derived from allometric equations (e.g. Thiel et al. 2015). Studies with remote sensing approaches (e.g. Black et al. 2014) were also excluded because the necessary ground truth data for these biomass estimates were not available. We compiled data on above-ground and below-ground biomass $\mathrm{C}$ stocks, along with additional information characterising the hedgerow (width, height, age, management, species composition). Biomass dry weight was converted to biomass $\mathrm{C}$ stocks if not already converted, based on the assumption that $47.5 \%$ of biomass dry weight constitutes C (Schlesinger and Bernhardt 2013). When width, height and age were given as a range over several sampled hedgerows, we calculated mean values. Descriptive statistics were applied to describe the biomass dataset and included mean, minimum/maximum values and variance, given in the text as standard deviations. All estimates of $\mathrm{C}$ stocks of hedgerows are given per hectare of hedgerow.

\section{Carbon sequestration}

Based on the estimates of $\mathrm{C}$ stocks in the biomass and soils of hedgerows, we calculated potential $\mathrm{C}$ sequestration rates from the establishment of new hedgerows. $\mathrm{C}$ sequestration must be quantified for a given duration. Only three studies with cropland as control land-use reported the time since hedgerow establishment and SOC stocks. We thus calculated SOC sequestration rates for only these studies as well as based on all studies with two scenarios assuming that both the SOC content of the hedgerows and that of the agricultural land were in equilibrium at the time of sampling. Based on the IPCC guidelines on National Greenhouse Gas Inventories (IPCC 2006c), we chose the Tier 1 default of 20 years as the period of transition between equilibrium SOC values. Additionally, we calculated a second scenario with a transition time of 50 years since it is known that the afforestation of croplands can lead to a long-lasting $\mathrm{C}$ sink and equilibrium will only be reached after decades (Poeplau et al. 2011). We assumed an average SOC stock of cropland of $54 \mathrm{Mg} \mathrm{C} \mathrm{ha}^{-1}$ in the topsoil according to Batjes (2010) and IPCC (2019a) as the baseline value for typical temperate croplands and the overall estimated relative increase of SOC after hedgerow establishment to calculate an annual SOC sequestration rate:

SOC sequestration rate $\left[\mathrm{Mg} \mathrm{ha}^{-1} \mathrm{yr}^{-1}\right]=\frac{\Delta \mathrm{SOC} * \mathrm{SOC}_{\text {baseline }}}{\Delta \mathrm{t}}$

where $\triangle \mathrm{SOC}$ represents the estimated relative SOC change (response ratio) after hedgerow establishment, $\mathrm{SOC}_{\text {baseline }}$ represents the baseline SOC stock $\left(54 \mathrm{Mg} \mathrm{C} \mathrm{ha}^{-1}\right)$ and $\Delta \mathrm{t}$ refers to the duration of the period of transition between equilibrium SOC values (20/50 years).

The management of hedgerows includes trimming, mostly annually and periodic rejuvenation through coppicing or layering, with techniques specific to the region (Baudry et al. 2000; Burel 1996). This leads to fluctuations in the biomass $\mathrm{C}$ stock (Fig. 1). To estimate a $\mathrm{C}$ sequestration rate in the biomass of hedgerows, we assumed that the biomass accumulation of hedgerows is linear until an average biomass 


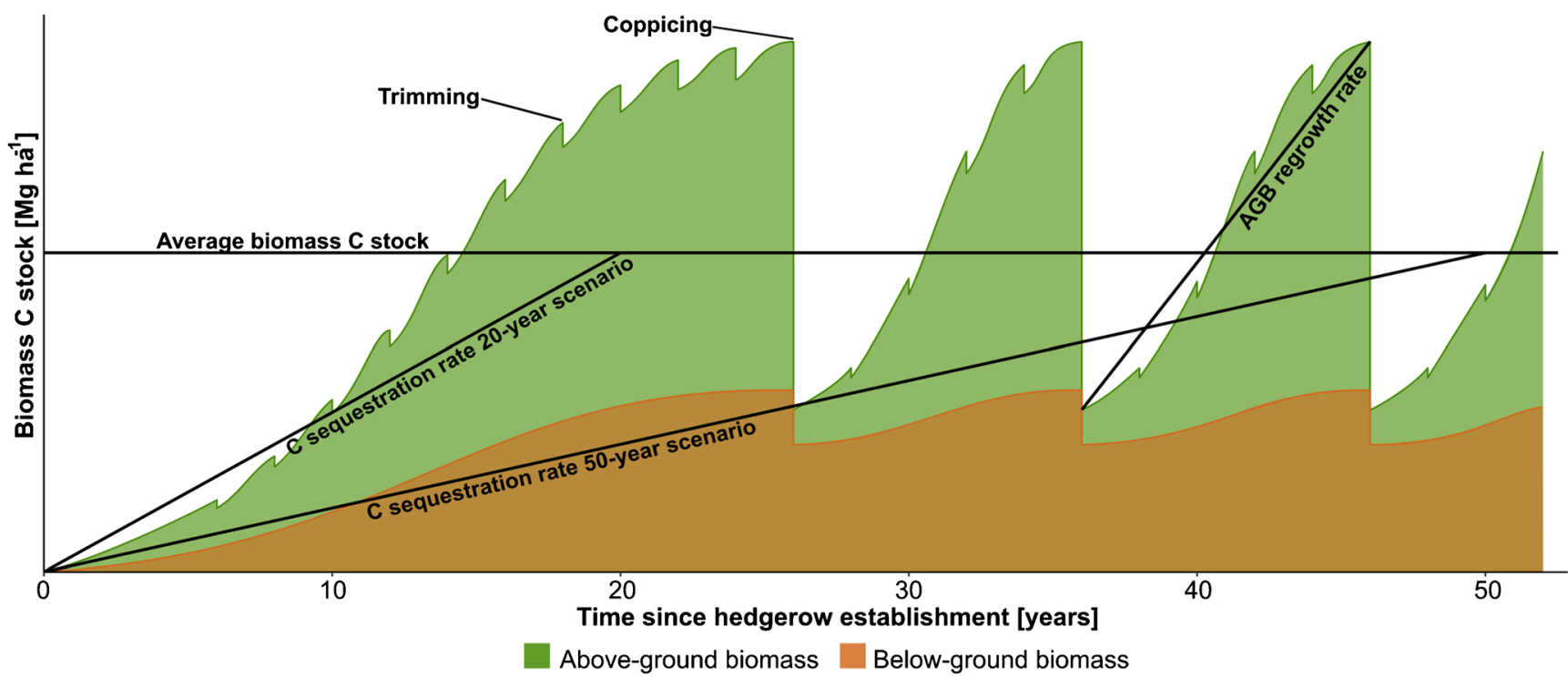

Fig. 1 Conceptual diagram of the dynamics of biomass accumulation after hedgerow establishment with regular trimming and coppicing. Carbon (C) sequestration was estimated as a linear rate until an average biomass $\mathrm{C}$ stock is reached for a period of 20 and 50 years, respectively,

C stock is reached (Fig. 1). Thus, the calculated sequestration rate represents an average $\mathrm{C}$ sequestration in hedgerow biomass and does not consider any dynamics of tree growth over time or fluctuations due to trimming and coppicing activities. We chose two scenarios until an average hedgerow biomass is accumulated, 20 and 50 years, respectively. Based on our results (Fig. 2), 20 years seems a realistic period for hedgerows to reach maturity. However, many hedgerows in the temperate climate zone also consist of trees. As trees need longer periods to reach maturity than shrubs, 50 years was chosen as the second scenario. To calculate $\mathrm{C}$ stock changes after hedgerow establishment, $\mathrm{C}$ stock changes due to the removal of $\mathrm{C}$ stored in the biomass of croplands and grasslands also need to be accounted for (IPCC 2019a). To compare the $\mathrm{C}$ stored in the biomass of hedgerows to adjacent agricultural fields, we assumed an average $\mathrm{C}$ stock in the thus representing the average sequestered carbon in hedgerow biomass and not taking biomass fluctuation due to management activities into account. The above-ground biomass (AGB) regrowth rate represents AGB accumulation after coppicing

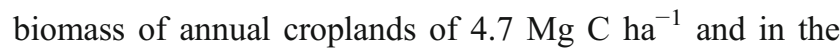
biomass of grasslands of $10.7 \mathrm{Mg} \mathrm{C} \mathrm{ha}^{-1}$ (IPCC 2006a).

\section{Results}

\section{Soil organic carbon stocks}

\section{Included studies}

The initial literature search yielded a total of 356 records, of which 46 were assessed in full-text. A flowchart of the study selection according to Moher et al. (2009) can be found in supplementary material (Online Resource Figure S.1). Our literature survey identified nine studies with 83 sampled hedgerows that matched the defined selection criteria and were used
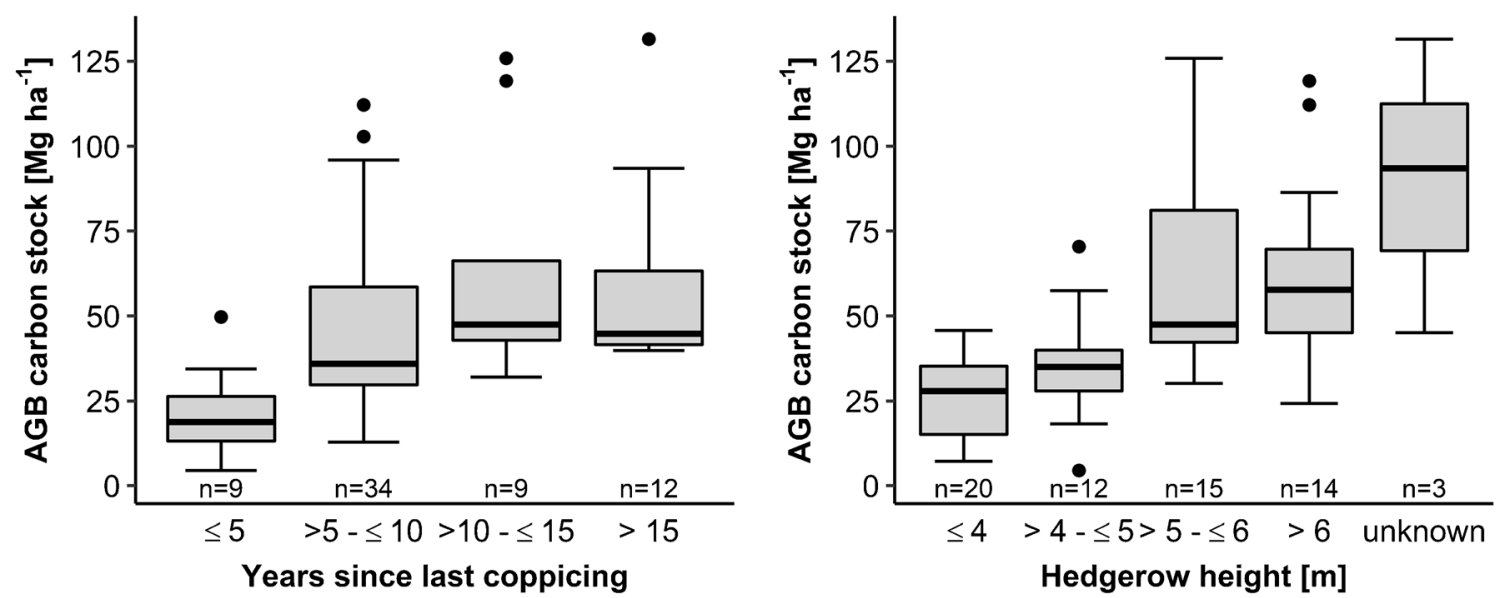

Fig. 2 Above-ground biomass (AGB) carbon stocks of the analysed hedgerows based on years since the last coppicing and hedgerow height 
for the meta-analyses. Eight of these studies had been peerreviewed, and one study had not. Most of the studies were not included due to uncertainty about whether the sampled hedgerow matched our hedgerow definition or was another type of field margin (e.g. D'Acunto et al. 2014; Wiesmeier et al. 2018). Other studies investigated SOC storage in hedgerow soils but had to be omitted due to a lack of control plots, in this case adjacent agricultural fields with a defined land-use (e.g. Walter et al. 2003). The included studies had been conducted all over the temperate climate zone (Table 1). Sampling depths ranged from 5 to $60 \mathrm{~cm}$, with up to three sampled depth increments. Five studies reported SOC stocks, while four reported SOC contents. The average sampling depth of all studies with a cropland control was $28.4 \mathrm{~cm}$. For studies with a grassland control, the average sampling depth was $15.5 \mathrm{~cm}$, weighted on the number of observations. Hedgerow age was reported in $55 \%$ of the studies and was weighted on the number of observations on average 39 years for hedgerows with a cropland control plot and 22 years for hedgerows adjacent to grassland.

\section{Effect of hedgerows on soil organic carbon stocks}

The meta-analysis showed that the establishment of hedgerows on cropland leads to a significant increase in SOC stocks
(Fig. 3). The SOC stock under hedgerows was on average 32 $\%$ higher than in the adjacent cropland, with a $95 \%$ confidence interval ranging from 15 to $51 \%$. Using the case of average temperate cropland, this translates into an SOC stock increase of $17 \pm 12 \mathrm{MgC} \mathrm{ha}^{-1}$ with the establishment of hedgerows on cropland. In contrast, the difference between SOC under hedgerows and adjacent grasslands was close to zero (average of $9 \%$ ). The $95 \%$ confidence intervals for the grassland overall estimate ranged from -30 to $19 \%$ and thus overlapped zero, indicating that the establishment of hedgerows compared with grassland has no statistically significant effect on SOC (Fig. 3). For both subgroups, considerable heterogeneity between the studies was observed (Fig. 3). Response ratios for the subgroup "cropland control" varied from -26 to $84 \%$ and for "grassland control" from -45 to $22 \%$. Test for heterogeneity was significant for both subgroups (cropland control: $\mathrm{Q}=34.15, \mathrm{df}=9$, $\mathrm{p}$ value $<0.001$; $\mathrm{I}^{2}=78.82 \%$; grassland control: $\mathrm{Q}=21.45, \mathrm{df}=5, \mathrm{p}$ value $\left.<0.001 ; \mathrm{I}^{2}=83.23 \%\right)$. However, except for the site of Paulsen and Bauer 2019_b in the "grassland control" subgroup, the confidence intervals of all studies overlapped with the overall estimate. Therefore, the direction and average magnitude of the treatment effect were robust for both subgroups. With the current dataset, it was not possible to identify an influence of

Table 1 Site characteristics of the included studies for the analysis of soil organic carbon stocks (MAP mean annual precipitation, MAT mean annual temperature, lowercase letters mark individual sites within one study)

\begin{tabular}{|c|c|c|c|c|c|c|}
\hline Reference & Country & $\begin{array}{l}\text { MAP } \\
{[\mathrm{mm}]}\end{array}$ & $\begin{array}{l}\text { MAT } \\
{\left[{ }^{\circ} \mathrm{C}\right]}\end{array}$ & Texture or soil type & $\begin{array}{l}\text { Hedgerow } \\
\text { age [years] }\end{array}$ & Dominant species \\
\hline $\begin{array}{l}\text { Baah-Acheamfour } \\
\text { et al. (2014) }\end{array}$ & Canada & $448-463$ & $\begin{array}{r}1.9- \\
2.4\end{array}$ & $\begin{array}{l}\text { Dark grey/black chernozemic } \\
\text { soils; grey luvisolic soils }\end{array}$ & $40-100$ & $\begin{array}{l}\text { Populus tremuloides, Betula papyrifera, } \\
\text { Populus balsamifera }\end{array}$ \\
\hline $\begin{array}{l}\text { Dhillon and Van } \\
\text { Rees (2017) }\end{array}$ & Canada & 455 & 3.2 & Brown soil & 18 & Caragna arborescens \\
\hline $\begin{array}{l}\text { Follain et al. } \\
\quad(2007)\end{array}$ & France & 746 & 10.3 & Loam & $\begin{array}{l}\text { Several } \\
\text { hun- } \\
\text { dreds of } \\
\text { years }\end{array}$ & Castanea sativa, Quercus robur \\
\hline Ford et al. (2019) & UK & 2500 & 9.0 & Loam/clay & $1 \rightarrow 40$ & $\begin{array}{l}\text { Crataegus monogyna, Prunus spinosa, Corylus } \\
\text { avellana }\end{array}$ \\
\hline $\begin{array}{l}\text { Holden et al. } \\
\text { (2019) }\end{array}$ & UK & 674 & 9.2 & Loam & No data & Crataegus monogyna, Sambucus nigra, Ilex aquifolium \\
\hline $\begin{array}{l}\text { Monokrousos } \\
\text { et al. (2006) }\end{array}$ & Greece & 506 & 15.7 & Loamy-clay & No data & $\begin{array}{l}\text { Rubus ulmifolius, Phragmites australis, Artemisia } \\
\quad \text { vulgaris }\end{array}$ \\
\hline $\begin{array}{l}\text { Paulsen and Bauer } \\
\text { (2008) }\end{array}$ & Germany & 735 & 8.7 & Loam & No data & $\begin{array}{l}\text { Fagus sylvatica, Corylus avellana, Crataegus } \\
\text { monogyna, Salix spec., Lonicera periclymenum, } \\
\text { Acer campestre, Quercus robur }\end{array}$ \\
\hline \multirow[t]{2}{*}{ Thiel et al. (2015) } & \multirow[t]{2}{*}{ Canada } & \multirow[t]{2}{*}{1228} & \multirow[t]{2}{*}{10.6} & \multirow[t]{2}{*}{ Silty-loam } & a: $\quad 9-19$ & $\begin{array}{c}\text { a: Thuja plicata, Acer rubrum, Acer macrophyllum, } \\
\text { Alnus rubra, Rosa nutkana, Cornus sericea }\end{array}$ \\
\hline & & & & & b: 38 & b: no data \\
\hline \multirow{4}{*}{$\begin{array}{l}\text { Van Vooren et al. } \\
\quad(2018)\end{array}$} & \multirow[t]{4}{*}{ Belgium } & \multirow[t]{4}{*}{784} & \multirow[t]{4}{*}{11.9} & \multirow[t]{4}{*}{ Sandy-loam/loam } & $\mathrm{a}:>100$ & a: Crataegus monogyna \\
\hline & & & & & b: 13 & b: Crataegus monogyna \\
\hline & & & & & c: 8 & $\begin{array}{l}\text { c: Crataegus monogyna, Sambucus nigra, } \\
\text { Corylus avellana, Fraxinus excelsior }\end{array}$ \\
\hline & & & & & $\mathrm{d}: \quad 10$ & $\mathrm{~d}$ : Carpinus betulus \\
\hline
\end{tabular}




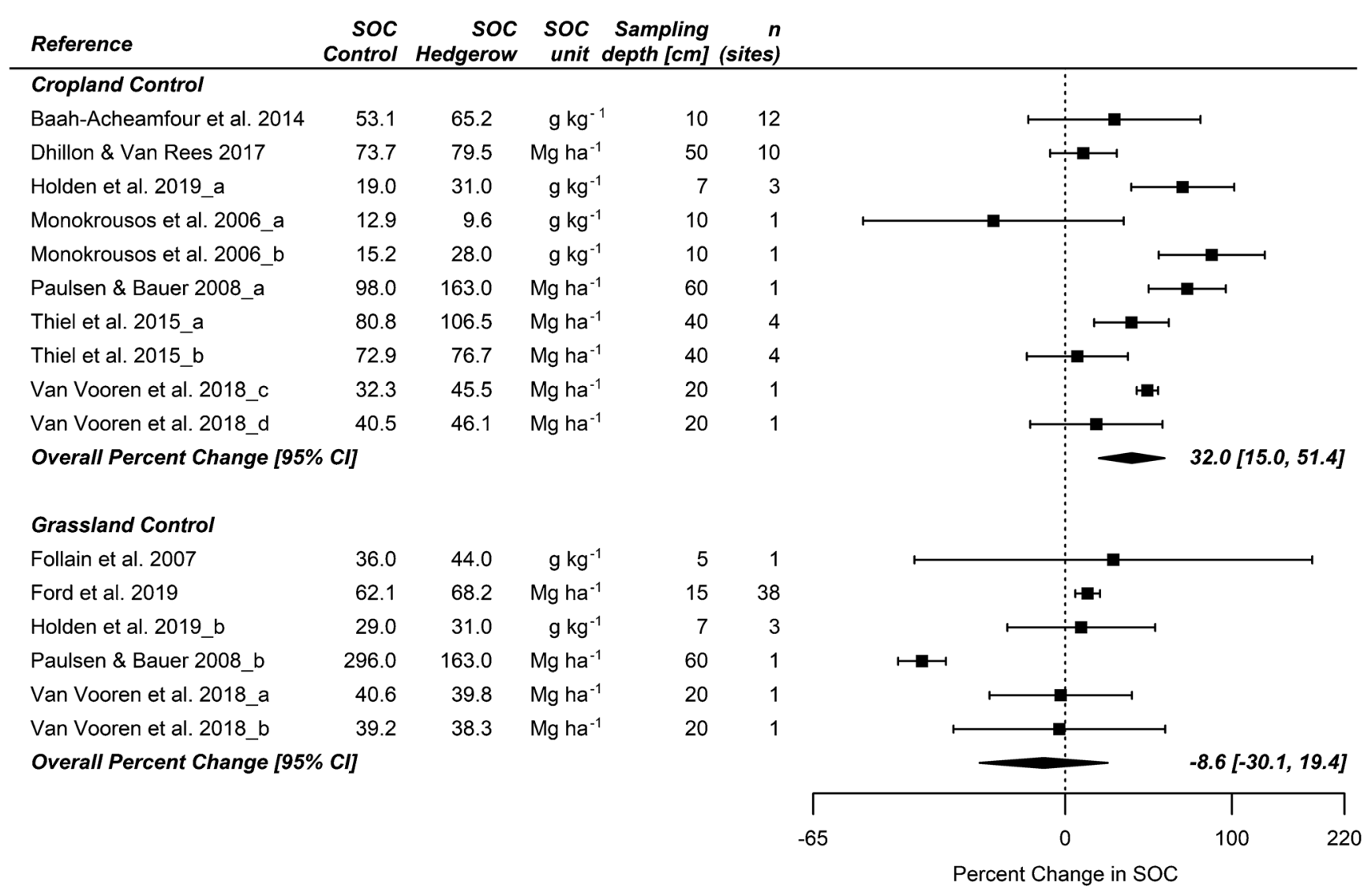

Fig. 3 Effect of hedgerows on soil organic carbon (SOC) stocks. Shown are individual mean effect sizes and $95 \%$ confidence intervals (CIs) as a percentage change (back-transformed log response ratio) for all studies. If a study provided data on more than one comparison between a hedgerow soil and an adjacent agricultural field, effect sizes were calculated for each

hedgerow age, soil texture or climate on the effect of hedgerow establishment on SOC storage (Online Resource Figure S.3). However, the fact that we could not observe a correlation with environmental parameters is not due to the lack of influence of these parameters on SOC accrual, but is due to the small dataset.

\section{Biomass carbon stocks}

\section{Included studies}

The dataset on biomass $\mathrm{C}$ stocks consisted of four peerreviewed studies plus our own data, totalling measurements of 64 hedgerows located in the UK and Germany. The mean hedgerow width was $4.0 \pm 2.1 \mathrm{~m}$, with a range from 1.0 to $11.6 \mathrm{~m}$, and the mean hedgerow height was $5.0 \pm 1.6 \mathrm{~m}$, with a range from 2.5 to $9.9 \mathrm{~m}$. Years since the last coppicing was on average $11.0 \pm 5.6$ years, ranging from 4 years to 28 years. The most frequently mentioned management techniques were annual/occasional trimming, hedge laying and periodic individual site within one study (marked by lowercase letters). The diamond shows the overall estimated percentage change using a randomeffects model for the two subgroups "cropland control" and "grassland control"

coppicing. Blackthorn (Prunus spinosa), hazel (Corylus avellana) and willow (Salix spec.) were the most abundant species (Online Resource Table S.2).

\section{Biomass carbon stocks}

Hedgerows stored on average $47 \pm 29 \mathrm{MgC} \mathrm{ha}^{-1}$ in the aboveground biomass. Above-ground biomass $\mathrm{C}$ stocks varied considerably, ranging from 4 (recently coppiced hedgerow) to $132 \mathrm{Mg} \mathrm{C} \mathrm{ha}{ }^{-1}$. Above-ground biomass $\mathrm{C}$ stocks showed increasing trends with years since the last coppicing and hedgerow height (Fig. 2), with a correlation between years since last coppicing and hedgerow height (Pearson's correlation coefficient $(r)=0.38, p<0.01)$. Below-ground biomass $\mathrm{C}$ stocks were only reported in two studies (Axe et al. 2017; Crossland 2015). Axe et al. (2017) measured three hedgerows down to $1 \mathrm{~m}$ depth. These sampled hedgerows had a mean $( \pm$ $S D$ ) root/shoot ratio of $0.94 \pm 0.26$ (Axe et al. 2017). In contrast, Crossland (2015) derived below-ground C biomass stocks from above-ground biomass $\mathrm{C}$ stocks via a fixed root/ 
shoot ratio of 0.33 . This assumed root/shoot ratio was not specific for the sampled hedgerows and therefore seems to underestimate below-ground biomass compared with the empirical values. Therefore, we took the measured root/shoot ratio by Axe et al. (2017) to estimate an average belowground biomass $\mathrm{C}$ stock. Axe et al. (2017) included the root crowns and the stools in the below-ground biomass. These components accounted for $43 \%$ of the below-ground biomass $\mathrm{C}$ stock and thus contributed to the high root/shoot ratio. However, since the data on above-ground biomass $\mathrm{C}$ stocks were derived from harvesting above-ground biomass with practices common for the region, the majority of the stools were not included in these $\mathrm{C}$ above-ground biomass stocks. The total biomass $\mathrm{C}$ stocks were therefore reasonably estimated. Accordingly, the below-ground biomass $\mathrm{C}$ stock of hedgerows was $44 \pm 28 \mathrm{Mg} \mathrm{C}^{-1}$, but with high uncertainty. In sum, the total biomass $\mathrm{C}$ stock of hedgerows was $92 \pm 40 \mathrm{Mg}$ $\mathrm{C} \mathrm{ha}{ }^{-1}$.

\section{Carbon sequestration}

The establishment of hedgerows on cropland could result in an additional SOC stock of $17 \mathrm{Mg} \mathrm{C} \mathrm{ha}^{-1}$ and thus in a SOC sequestration of $0.9 \mathrm{Mg} \mathrm{C}^{-1}$ year $^{-1}$ over a 20 -year period. Based on a 50 -year scenario to reach equilibrium, the SOC sequestration rate would be $0.3 \mathrm{Mg} \mathrm{ha}^{-1}$ year $^{-1}$. We obtained a mean SOC sequestration rate of $0.7 \mathrm{MgC} \mathrm{ha}^{-1}$ year $^{-1}$ if only studies that reported hedgerow ages and SOC stocks (3 out of 7 studies) were included. This value is similar to the mean SOC sequestration range obtained from all studies. Assuming hedgerow biomass reaches maturity after 20 years of hedgerow establishment on cropland, $4.3 \mathrm{Mg} \mathrm{C}^{-1}$ year $^{-1}$ accumulates in the hedgerow biomass over this 20 -year period. With an establishment time of 50 years, the $\mathrm{C}$ accumulation in the hedgerow biomass would be $1.7 \mathrm{Mg} \mathrm{C} \mathrm{ha}^{-1}$ year $^{-1}$. In total, hedgerows stored $104 \pm 42 \mathrm{Mg} \mathrm{C}$ ha $^{-1}$ more $\mathrm{C}$ than croplands, with biomass and soil contributing about $84 \%$ and $16 \%$, respectively. Therefore, the total estimated $\mathrm{C}$ sequestration with the establishment of hedgerows on cropland was $5.2 \mathrm{Mg} \mathrm{C}^{-1}$ year $^{-1}$ for a period of 20 years or $2.1 \mathrm{Mg} \mathrm{C}$ $\mathrm{ha}^{-1}$ year $^{-1}$ for a 50 -year scenario. Hedgerow establishment on grassland did not sequester additional SOC, but did accumulate similar amounts of biomass. On grasslands, hedgerows stored additional $81 \pm 40 \mathrm{Mg} \mathrm{C} \mathrm{ha}^{-1}$ in the biomass.

\section{Discussion}

\section{Soil organic carbon stocks}

Our study showed that by establishing hedgerows on former cropland in the temperate climate zone, SOC increased by 32 $\pm 23 \%$ on average. This result is similar to estimates of land- use change from cropland to forests. In their meta-analysis on the effect of afforestation on SOC stocks, Barcena et al. (2014) showed a SOC stock increase of $20 \%$ in $0-10 \mathrm{~cm}$ sampling depth after the afforestation of croplands. Poeplau and Don (2013) found a SOC accumulation of $21 \pm 13 \mathrm{Mg} \mathrm{ha}^{-1}$ after the land-use change from cropland to forest, which is in good agreement with our estimate for the establishment of hedgerows $\left(17 \pm 12 \mathrm{Mg} \mathrm{ha}^{-1}\right)$.

As one of the few reviews analysing the effect of hedgerows, Van Vooren et al. (2017) estimated that the SOC stock beneath hedgerows is $22 \%$ higher than that in adjacent agricultural fields. The estimate was based on eight published studies and their own data. However, tree rows and alley cropping systems were also counted as hedgerows, and no differentiation was made between cropland and grassland as the control, which could have produced the lower estimate. We only compiled data from studies with hedgerows that contained shrubby vegetation and had a clear control landuse (cropland/grassland). Therefore, our included studies differed from those considered in the review by Van Vooren et al. (2017). In their global meta-analysis on $\mathrm{C}$ storage of agroforestry systems, Cardinael et al. (2018b) also differentiated hedgerows. Based on five studies with 21 observations, Cardinael et al. (2018b) found a relative increase of $21 \%$ SOC comparing hedgerows to cropland in the temperate climate zone. Similar to Van Vooren et al. (2018), Cardinael et al. (2018b) included data from shelterbelts, windbreaks and live fences. Thus, the definition of hedgerows is different from this study, and consequently the studies considered by Cardinael et al. (2018b) differ (overlap of two studies) from the data used in our meta-analysis.

We could not observe a statistically significant trend in SOC storage for the establishment of hedgerows on grasslands. This is also consistent with other studies and meta-analyses, which found no significant SOC changes comparing different agroforestry systems and grassland (Beckert et al. 2015; De Stefano and Jacobson 2018; Fornara et al. 2018). As regions dominated by cropland are under more environmental pressure than grasslands (Kay et al. 2019), the establishment of hedgerows on cropland is also likely to achieve the best synergies with other ecosystem functions, such as enhancement of biodiversity, improvement of microclimatic conditions and erosion control. It must be considered that the gain in SOC is reversible. However, as the establishment of hedgerows is often associated with a permanent obligation from the landowner, e.g. in Europe through European Cross Compliance Regulations (Regulation (EU) No 1306/2013 2013), it is a promising management option for permanent SOC storage.

Considerable heterogeneity was observed between the studies. One reason for the heterogeneity could be that the analysed hedgerow types were quite diverse, although we applied a narrow hedgerow definition as study selection 
criterion. Plant composition and hedgerow characteristics, such as height, affect hedgerow SOC storage (Dhillon and Van Rees 2017). Hedgerow age also likely has an impact on SOC, although we could not observe an influence of hedgerow age on the effect of hedgerows on SOC storage due to the limited dataset. Chatterjee et al. (2018) and Dhillon and Van Rees (2017) showed that older agroforestry systems have larger SOC stocks than newly established systems. However, after decades, a new steady state will be reached in SOC if environmental conditions and management are unchanged. The effect of hedgerow age on SOC storage is probably not visible due to an overlap with other influencing factors. In addition, Ford et al. (2019) stated that hedgerows are often replanted where hedgerows once existed. Such land-use history could also blur the effect of hedgerow age on SOC. Owing to the limited number of studies and reported explanatory variables, we could not further analyse other influencing factors on SOC storage of hedgerows.

Inconsistencies in study design and a lack of standardised sampling procedures could have added heterogeneity in the study effects and influenced the overall outputs. The sampling depths differed greatly between 5 and $60 \mathrm{~cm}$ and often were not deep enough. Tree and shrub roots in agroforestry systems extend to deep soil horizons and thus can critically affect the subsoil's SOC stock (Haile et al. 2010). Nair (2012) emphasised that tree-based systems need to be studied to at least $1 \mathrm{~m}$ depth to detect the complete impact of land-use on SOC stocks. Mulia and Dupraz (2006) found fine roots up to $2.5 \mathrm{~m}$ depth in a poplar agroforestry system and up to $3 \mathrm{~m}$ depth in a walnut agroforestry system in France. Cardinael et al. (2015) even sampled fine roots down to $4 \mathrm{~m}$ depth within that walnut agroforestry system in France and found that roots within the agroforestry system were more pronounced in deeper soil layers compared to walnut trees planted in monoculture. Another issue was that four of the nine compiled studies reported SOC contents only and no stocks. Even when SOC stocks were reported, bulk densities were mostly not given. Therefore, it was not possible to account for differing bulk densities of the paired-plots and perform a mass correction for all data (Ellert and Bettany 1995). Due to higher SOC contents, the bulk densities under hedgerows were lower in all studies with reported bulk densities (Dhillon and Van Rees 2017; Ford et al. 2019; Holden et al. 2019; Paulsen and Bauer 2008; Thiel et al. 2015). This could lead to an underestimation of mass-corrected SOC stocks in hedgerow soils compared with adjacent croplands. Regarding the sampling design, some soil samples were taken from directly beneath the hedgerow, whereas other samples were taken next to the hedgerow (e.g. Van Vooren et al. 2018). If an SOC gradient from inside the hedgerow to the outside can be assumed, sampling next to the hedgerow could also have led to an underestimation of hedgerow SOC. Although the area close to the hedgerow may still be influenced by the root system and litterfall of the hedgerow, the area directly beneath the hedgerow is likely to store more SOC (Cardinael et al. 2015). These limitations stress the need for more comprehensive studies analysing the SOC stocks of hedgerow soils.

\section{Biomass carbon stocks}

With an average of $92 \pm 40 \mathrm{Mg} \mathrm{C} \mathrm{ha}^{-1}$, hedgerows can store similar amounts of biomass $\mathrm{C}$ to forests. Temperate forests in Germany store on average $103 \mathrm{Mg} \mathrm{C} \mathrm{ha}^{-1}$, according to the National Forest Inventory (Wellbrock et al. 2017). The reported above-ground biomass $\mathrm{C}$ stocks of hedgerows ranged from 4 to $132 \mathrm{Mg} \mathrm{C}^{-1}$. This variability can be explained by hedgerow characteristics, e.g. height, age and species composition, and by site characteristics, e.g. precipitation, which influence primary production. Furthermore, hedgerow management, such as trimming and coppicing frequency, influences the biomass of hedgerows (Crossland 2015; Czerepowicz et al. 2012). The hedgerows in our dataset were coppiced different times ago, ranging from 4 to 28 years (Online Resource Figure S.4). The average of $92 \pm 40 \mathrm{Mg} \mathrm{C}$ $\mathrm{ha}^{-1}$ is thus representing the average amount of $\mathrm{C}$ in a hedgerow system independent of fluctuations due to hedgerow management.

For our dataset, we could confirm a biomass $\mathrm{C}$ stock increase with years since the last coppicing and hedgerow height (Fig. 2). Robertson et al. (2012) showed that hedgerow height is also correlated with hedgerow type, with tree-dominated hedgerows being taller and storing more $\mathrm{C}$ than shrubdominated hedgerows. They proposed that hedgerow height could be used to estimate the biomass of hedgerows. Axe et al. (2017) confirmed this relationship, but with limitations regarding recently trimmed hedgerows. Our results suggest that time since the last coppicing event could also be used instead of height to estimate above-ground biomass because we found a correlation between time since last coppicing and hedgerow height.

As only one of the studies measured below-ground $\mathrm{C}$ stocks, there is clearly a need for more field-based measurements, especially of below-ground biomass stocks of hedgerows, to derive more thorough estimates. Roots contribute substantially to the overall $\mathrm{C}$ stock of hedgerows. Axe et al. (2017) measured almost equivalent below-ground and aboveground biomass stocks. Their measured hedgerow root/shoot ratio of $0.94 \pm 0.26$ is much higher than the root/shoot ratio of temperate forests, which was estimated to be between 0.30 and 0.46 , depending on forest vegetation type and shoot biomass, in a global meta-analysis by Mokany et al. (2006). However, it was not as high as the root/shoot ratio for shrubland at 1.84 (Mokany et al. 2006). The high root/shoot ratio of hedgerows in the temperate climate zone could be attributed to the regular above-ground disturbance by periodic trimming and coppicing. Regular above-ground disturbance generally 
leads to higher root/shoot ratios (Mokany et al. 2006). Additionally, specific hedgerow management, such as laying and coppicing, results in multiple, small stems growing from one stool. The stool and root crowns add substantial biomass to the root biomass stock (Axe et al. 2017).

\section{Carbon sequestration}

We calculated a SOC sequestration rate of between 0.3 (50year scenario) and $0.9 \mathrm{Mg} \mathrm{C} \mathrm{ha}^{-1}$ year $^{-1}$ (20-year scenario) for the establishment of hedgerows on cropland. Cardinael et al. (2018b) also derived SOC sequestration rates for the establishment of hedgerows on cropland in the temperate climate zone. Their estimate of $0.45 \mathrm{Mg} \mathrm{C}^{-1}$ year $^{-1}$ is closer to our 50-year scenario. According to our data, between 1.7 and 4.3 $\mathrm{Mg} \mathrm{C} \mathrm{ha}{ }^{-1}$ year $^{-1}$ accumulated in the hedgerow biomass after hedgerow establishment on cropland over 50 and 20 years, respectively. Assuming a hedgerow width of $5 \mathrm{~m}$, the estimate provided by Cardinael et al. (2018b) is $1.7 \mathrm{MgC} \mathrm{ha}^{-1}$ year $^{-1}$ above-ground biomass production and $0.5 \mathrm{Mg} \mathrm{C}^{-1}$ year $^{-1}$ below-ground biomass production, totalling $2.2 \mathrm{Mg} \mathrm{C}$ $\mathrm{ha}^{-1}$ year $^{-1}$, and is thus closer to our 50-year scenario. Although acknowledged by the IPCC (IPCC 2019a), the biomass $\mathrm{C}$ sequestration estimates derived by Cardinael et al. (2018b) are based on only one study in which above-ground biomass of 12 shelterbelts was measured. Below-ground biomass was estimated with a fixed root/shoot ratio of 0.26 . According to the empirical data by Axe et al. (2017), this root/shoot ratio underestimates below-ground biomass of hedgerows in the temperate climate zone. Thus, we have assumed a higher accumulation of below-ground biomass. Moreover, the estimates for hedgerow biomass given by Cardinael et al. (2018b) are not on an area basis but on per $\mathrm{km}$ hedgerow; comparisons are difficult.

Estimating C stocks and sequestration of linear objects, such as hedgerows, on an area basis is prone to errors since it is hard to measure the exact hedgerow width. The hedgerow width can be defined either as the crown width or as the width of the stems at the hedgerow base, which are usually different. This context also leads to the conclusion that as well as establishing new hedgerows, allowing existing hedgerows to grow wider will also sequester $\mathrm{C}$. This was suggested by Axe et al. (2017) and by Falloon et al. (2004), who theoretically calculated $\mathrm{C}$ sequestration potentials for different hedgerow widths.

Our study clearly showed that the establishment of hedgerows increases $\mathrm{C}$ stocks, both in the soil (on former croplands) and in the biomass, and is therefore an effective option for $\mathrm{C}$ sequestration. The overall potential to increase the $\mathrm{C}$ stock was substantial, although the calculated sequestration rates are only a first estimation due to the lack of field data on the dynamics of $\mathrm{C}$ sequestration under hedgerows. Hedgerows are permanent vegetation and thus can assimilate $\mathrm{C}$ without a fallow period throughout the year if leaves are present. Compared to annually harvested cropland, there is no or only minor export of biomass from hedgerows, which increases $\mathrm{C}$ inputs to the soil. In addition, extensive root systems can develop under hedgerows over the years. Root litter has been found to contribute considerably to building up SOC (Kätterer et al. 2011; Rasse et al. 2005). Hedgerows have a complex structure, with mostly a combination of trees and shrubs and often grass cover beneath and next to them. Compared with forests, hedgerows have stems of a smaller diameter, but with denser spacing (Axe et al. 2017). This promotes a high biomass both above- and below-ground and subsequently favours $\mathrm{C}$ input to the soil and SOC formation. Substantial parts of the overall $\mathrm{C}$ pool in hedgerow ecosystems are also stored in the organic layer, in surface litter, in deadwood and, if present, in herbaceous vegetation (Axe et al. 2017; Welsch et al. 2016). From the included studies, the extent to which these components were included in biomass data, if at all, was not always clear. This could have caused an underestimation of total hedgerow $\mathrm{C}$ stocks. Litterfall from hedgerows and root systems exceeding the hedgerows may also contribute to building up SOC in the vicinity of the hedges, as found by Cardinael et al. (2015). This additional $C$ sequestration effect could not be accounted for in our study either due to the lack of data.

Hedgerow biomass is traditionally harvested with regular trimming and periodic coppicing every 5 to 15 years. However, in most regions, this practice has been performed less and less in recent decades due to the considerable workload, high costs and insufficient options to use or sell the woody biomass of hedgerows (Lotfi et al. 2010; Wolton 2012). If the biomass is cut, it is often not used (e.g. for heating purposes) but left on the ground as woody debris or burnt on site. Not using the biomass affects not only the hedgerows' ecological functions, but can also have a negative effect on the total $\mathrm{C}$ budget, thus reducing the maximum achievable climate mitigation potential of hedgerows. The annual energy production of hedgerows can be $76 \mathrm{GJ}^{\mathrm{h}} \mathrm{a}^{-1}$ year $^{-1}$, based on an above-ground biomass regrowth rate of $4 \mathrm{Mg}$ dry mass ha ${ }^{-1}$ year $^{-1}$ (Axe et al. 2017; Lingner et al. 2018; Seidel et al. 2015) and a calorific value of woodchips from hedgerows of $19 \mathrm{GJ} \mathrm{Mg}^{-1}$ (Chambers et al. 2015). One hectare of hedgerow biomass would therefore provide heating energy for about two households, with an average annual energy consumption for heating of 37 GJ per dwelling in the European Union in 2017 (Odyssee-Mure 2020). Using Tier 1 default factors (IPCC 2006b) for (net) calorific values and $\mathrm{CO}_{2}$ emission factors, one hectare of harvested hedgerow biomass could substitute $1.6 \mathrm{Mg}$ natural gas or $1.8 \mathrm{Mg}$ light fuel oil per year. This translates a mitigation of $1.2 \mathrm{MgC} \mathrm{ha}^{-1}$ year $^{-1}$ (substituting natural gas) or $1.5 \mathrm{Mg} \mathrm{C}^{-1}$ year $^{-1}$ (substituting light fuel oil). Compared with the total $\mathrm{C}$ sequestration of $5.2 \mathrm{Mg} \mathrm{C} \mathrm{ha}^{-1}$ year $^{-1}$ (20-year scenario), this is a 
relevant component increasing the mitigation effect of hedgerows by about a quarter. Compared to our 50-year scenario (2.1 $\mathrm{Mg} \mathrm{C} \mathrm{ha}^{-1}$ year $\left.^{-1}\right)$, the use of biomass would even increase the mitigation effect by about two-thirds.

The above derived estimates can only give an initial estimation of the amount of possible fossil fuel substitution through the use of hedgerow biomass. For a full life cycle assessment, biomass losses along the supply chain and other emissions, e.g. for transportation, must be taken into account (Wolf et al. 2016). However, the calculation shows that the use of hedgerow biomass can have a substantial additional climate mitigation effect by substituting fossil fuels. Crossland (2015) modelled the C stocks and fluxes of coppiced versus un-coppiced hedgerows and found that while uncoppiced hedgerows sequester larger quantities of $\mathrm{C}$, total $\mathrm{C}$ savings are higher when hedges are managed by coppicing due to the substitution of fossil fuels via the production of wood fuel. In contrast to $\mathrm{C}$ sequestration in the biomass and soil of hedgerows, which occurs once, this climate change mitigation potential exists repeatedly while non-renewable energy that can be substituted is used. However, even in a $100 \%$ renewable energy world where fossil fuels are no longer required to be substituted, hedgerow biomass can contribute to energy security with bioenergy from agriculture produced mainly in rural areas.

\section{Conclusions}

The positive effects of hedgerow establishment on C stocks and potential fossil fuel substitution have not been sufficiently recognised up to now. This study provides a quantitative overview of $\mathrm{C}$ stocks in hedgerow ecosystems, based on own biomass data and data from other empirical studies. Hedgerows were strictly defined as linear structures containing perennial shrubs or shrubs and trees. Our results clearly indicate that the establishment of hedgerows in agricultural areas, especially on cropland, can be an effective and multifunctional measure to sequester C. Conversely, the removal of hedgerows would be a potential $\mathrm{C}$ source. We found an average relative SOC increase of $32 \pm 23 \%$ after the establishment of hedgerows on cropland and a hedgerow biomass $\mathrm{C}$ stock of $92 \pm 40 \mathrm{Mg} \mathrm{Cha}^{-1}$. Since hedgerows are permanent elements in the landscape, the problem of loss of sequestered $\mathrm{C}$ (reversibility) is largely solved. This makes the establishment of hedgerows for $\mathrm{C}$ sequestration a particularly promising option for climate change mitigation. Moreover, hedgerows provide a wealth of additional ecosystem services, and they only require a small area of agricultural land, thus leaving most agricultural land for food production. In Germany, for example, hedgerows only cover about $0.2 \%$ of agricultural land today, according to the digital landscape model. Our results can help quantify changes in $\mathrm{C}$ stocks associated with the removal or establishment of hedgerows and support the promotion of hedgerow preservation and establishment in discussions about climate change mitigation and adaptation.

Supplementary Information The online version contains supplementary material available at https://doi.org/10.1007/s10113-021-01798-8.

Acknowledgements We thank Stefanie Pöpken for conducting the elaborate fieldwork, sampling 49 hedgerows for above-ground biomass. We thank all the authors of the included studies who provided additional data: Les Firbank, Hans Marten Paulsen, Eiko Thiessen and Kris Verheyen. Further thanks to Mirjam Helfrich, Sofia Heukrodt, Tino Peplau, Christopher Poeplau, Catharina Riggers, Ali Sakhaee and Florian Schneider for their valuable feedback on this manuscript.

Funding Open Access funding enabled and organized by Projekt DEAL.

Open Access This article is licensed under a Creative Commons Attribution 4.0 International License, which permits use, sharing, adaptation, distribution and reproduction in any medium or format, as long as you give appropriate credit to the original author(s) and the source, provide a link to the Creative Commons licence, and indicate if changes were made. The images or other third party material in this article are included in the article's Creative Commons licence, unless indicated otherwise in a credit line to the material. If material is not included in the article's Creative Commons licence and your intended use is not permitted by statutory regulation or exceeds the permitted use, you will need to obtain permission directly from the copyright holder. To view a copy of this licence, visit http://creativecommons.org/licenses/by/4.0/.

\section{References}

Aertsens J, De Nocker L, Gobin A (2013) Valuing the carbon sequestration potential for European agriculture. Land Use Policy 31:584 594. https://doi.org/10.1016/j.landusepol.2012.09.003

Albrecht A, Kandji ST (2003) Carbon sequestration in tropical agroforestry systems. Agric Ecosyst Environ 99:15-27. https://doi.org/10. 1016/s0167-8809(03)00138-5

Amichev BY, Laroque CP, Van Rees KCJE (2020) Shelterbelt removals in Saskatchewan, Canada: implications for long-term carbon sequestration. Agroforestry Systems. doi:https://doi.org/10.1007/ s10457-020-00484-8

Arrouays D, Balesdent J, Germon JC, Jayet PA, Soussana JF et al (eds) (2002) Contribution à la lutte contre l'effet de serre. Stocker du carbone dans les sols agricoles de France? INRA Editions, Paris, $332 \mathrm{pp}$.

Axe MS, Grange ID, Conway JS (2017) Carbon storage in hedge biomass - a case study of actively managed hedges in England. Agric Ecosyst Environ 250:81-88. https://doi.org/10.1016/j.agee. 2017.08.008

Baah-Acheamfour M, Carlyle CN, Bork EW, Chang SX (2014) Trees increase soil carbon and its stability in three agroforestry systems in central Alberta, Canada. For Ecol Manag 328:131-139. https://doi. org/10.1016/j.foreco.2014.05.031

Barcena TG, Kiaer LP, Vesterdal L, Stefansdottir HM, Gundersen P et al (2014) Soil carbon stock change following afforestation in Northern Europe: a meta-analysis. Glob Chang Biol 20:2393-2405. https:// doi.org/10.1111/gcb.12576

Barr CJ, Gillespie MK (2000) Estimating hedgerow length and pattern characteristics in Great Britain using Countryside Survey data. J Environ Manag 60:23-32. https://doi.org/10.1006/jema.2000.0359 
Batjes NH (2010) A global framework of soil organic carbon stocks under native vegetation for use with the simple assessment option of the Carbon Benefits Project system. Report 2010/10, Carbon Benefits Project (CBP) and ISRIC - World Soil Information, Wageningen. doi:10.13140/2.1.1423.1844

Batjes NH (2014) Total carbon and nitrogen in the soils of the world. Eur J Soil Sci 65:10-21. https://doi.org/10.1111/ejss.12114_2

Baudry J, Bunce RGH, Burel F (2000) Hedgerows: an international perspective on their origin, function and management. J Environ Manag 60:7-22. https://doi.org/10.1006/jema.2000.0358

Beckert MR, Smith P, Lilly A, Chapman SJ (2015) Soil and tree biomass carbon sequestration potential of silvopastoral and woodlandpasture systems in North East Scotland. Agrofor Syst 90:371-383. https://doi.org/10.1007/s10457-015-9860-4

Bird PR, Jackson TT, Kearney GA, Roache A (2007) Effects of windbreak structure on shelter characteristics. Aust J Exp Agric 47:727737. https://doi.org/10.1071/EA06086

Black K, Green S, Mullooley G, Poveda A (2014) Carbon sequestration by hedgerows in the Irish landscape. Towards a national hedgerow biomass inventory for the LULUCF sector using LiDAR remote sensing. CCRP Report. Environmental Protection Agency, Wexford, Ireland

Borenstein M, Hedges LV, Higgins JP, Rothstein HR (2010) A basic introduction to fixed-effect and random-effects models for metaanalysis. Res Synth Methods 1:97-111. https://doi.org/10.1002/ jrsm. 12

Burel F (1996) Hedgerows and their role in agricultural landscapes. Crit Rev Plant Sci 15:169-190. https://doi.org/10.1080/07352689.1996. 10393185

Cardinael R, Chevallier T, Barthès BG, Saby NPA, Parent T et al (2015) Impact of alley cropping agroforestry on stocks, forms and spatial distribution of soil organic carbon - a case study in a Mediterranean context. Geoderma:259-260. https://doi.org/10. 1016/j.geoderma.2015.06.015

Cardinael R, Guenet B, Chevallier T, Dupraz C, Cozzi T et al (2018a) High organic inputs explain shallow and deep SOC storage in a long-term agroforestry system - combining experimental and modeling approaches. Biogeosciences 15:297-317. https://doi.org/ 10.5194/bg-15-297-2018

Cardinael R, Umulisa V, Toudert A, Olivier A, Bockel L et al (2018b) Revisiting IPCC Tier 1 coefficients for soil organic and biomass carbon storage in agroforestry systems. Environ Res Lett 13. https://doi.org/10.1088/1748-9326/aaeb5f

Chambers M, Crossland M, Westaway S, Smith J (2015) Hedgerow harvesting machinery trial report. The Organic Research Centre, Elm Farm

Chatterjee N, Nair PKR, Chakraborty S, Nair VD (2018) Changes in soil carbon stocks across the forest-agroforest-agriculture/pasture continuum in various agroecological regions: $s$ meta-analysis. Agric Ecosyst Environ 266:55-67. https://doi.org/10.1016/j.agee.2018. 07.014

Crossland M (2015) The carbon sequestration potential of hedges managed for woodfuel. The Organic Research Centre, Elm Farm

Czerepowicz L, Case BS, Doscher C (2012) Using satellite image data to estimate aboveground shelterbelt carbon stocks across an agricultural landscape. Agric Ecosyst Environ 156:142-150. https://doi.org/ 10.1016/j.agee.2012.05.014

D'Acunto L, Semmartin M, Ghersa CM (2014) Uncropped field margins to mitigate soil carbon losses in agricultural landscapes. Agric Ecosyst Environ 183:60-68. https://doi.org/10.1016/j.agee.2013. 10.022

De Stefano A, Jacobson MG (2018) Soil carbon sequestration in agroforestry systems: a meta-analysis. Agrofor Syst 92:285-299. https:// doi.org/10.1007/s10457-017-0147-9
Dhillon GS, Van Rees KCJ (2017) Soil organic carbon sequestration by shelterbelt agroforestry systems in Saskatchewan. Can J Soil Sci 97: 394-409. https://doi.org/10.1139/cjss-2016-0094

Dittmann S, Thiessen E, Hartung E (2017) Applicability of different noninvasive methods for tree mass estimation: a review. For Ecol Manag 398:208-215. https://doi.org/10.1016/j.foreco.2017.05.013

Ellert BH, Bettany JR (1995) Calculation of organic matter and nutrients stored in soils under contrasting management regimes. Can J Soil Sci 75:529-538. https://doi.org/10.4141/cjss95-075

Falloon P, Powlson D, Smith P (2004) Managing field margins for biodiversity and carbon sequestration: a Great Britain case study. Soil Use Manag 20:240-247. https://doi.org/10.1079/sum2004236

Federal Government (2019) Key elements of the climate action programme $2030 \mathrm{https}: /$ www.bundesregierung.de/breg-en/issues/ climate-action/klimaschutzziele-finanzieren-1694724.

Feliciano D, Ledo A, Hillier J, Nayak DR (2018) Which agroforestry options give the greatest soil and above ground carbon benefits in different world regions? Agric Ecosyst Environ 254:117-129. https://doi.org/10.1016/j.agee.2017.11.032

Follain S, Walter C, Legout A, Lemercier B, Dutin G (2007) Induced effects of hedgerow networks on soil organic carbon storage within an agricultural landscape. Geoderma 142:80-95. https://doi.org/10. 1016/j.geoderma.2007.08.002

Ford H, Healey JR, Webb B, Pagella TF, Smith AR (2019) How do hedgerows influence soil organic carbon stock in livestock-grazed pasture? Soil Use Manag. https://doi.org/10.1111/sum.12517

Forman RTT, Baudry J (1984) Hedgerows and hedgerow networks in landscape ecology. Environ Manag 8:495-510. https://doi.org/10. 1007/BF01871575

Fornara DA, Olave R, Burgess P, Delmer A, Upson M et al (2018) Land use change and soil carbon pools: evidence from a long-term silvopastoral experiment. Agrofor Syst 92:1035-1046. https://doi. org/10.1007/s10457-017-0124-3

Fuss S, Canadell JG, Peters GP, Tavoni M, Andrew RM et al (2014) Betting on negative emissions. Nat Clim Chang 4:850-853. https://doi.org/10.1038/nclimate2392

Gruenewald H, Brandt BKV, Schneider BU, Bens O, Kendzia G et al (2007) Agroforestry systems for the production of woody biomass for energy transformation purposes. Ecol Eng 29:319-328. https:// doi.org/10.1016/j.ecoleng.2006.09.012

Haddaway NR, Brown C, Eales J, Eggers S, Josefsson J et al (2018) The multifunctional roles of vegetated strips around and within agricultural fields. Environmental Evidence 7. doi:https://doi.org/10.1186/ s13750-018-0126-2

Haile SG, Nair VD, Nair PKR (2010) Contribution of trees to carbon storage in soils of silvopastoral systems in Florida, USA. Glob Chang Biol 16:427-438. https://doi.org/10.1111/j.1365-2486. 2009.01981.x

Hedges LV, Gurevitch J, Curtis PS (1999) The meta-analysis of response ratios in experimental ecology. Ecology 80:1150-1156. https://doi. org/10.2307/177062

Higgins JPT, Thompson SG (2002) Quantifying heterogeneity in a metaanalysis. Stat Med 21:1539-1558. https://doi.org/10.1002/sim.1186

Holden J, Grayson RP, Berdeni D, Bird S, Chapman PJ et al (2019) The role of hedgerows in soil functioning within agricultural landscapes. Agric Ecosyst Environ 273:1-12. https://doi.org/10.1016/j.agee. 2018.11.027

Holzmueller EJ, Jose S (2012) Biomass production for biofuels using agroforestry: potential for the North Central Region of the United States. Agrofor Syst 85:305-314. https://doi.org/10.1007/s10457$012-9502-\mathrm{z}$

IPCC (2006a) 2006 IPCC Guidelines for National Greenhouse Gas Inventories. Chapter 6: Grassland. Calvo Buendia, E., Tanabe, K., Kranjc, A., Baasansuren, J., Fukuda, M., Ngarize S., Osako, A., Pyrozhenko, Y., Shermanau, P. and Federici, S.(eds). Published: IPCC, Switzerland. 
IPCC (2006b) 2006 IPCC Guidelines for National Greenhouse Gas Inventories. Volume 2: Energy. IGES, Japan

IPCC (2006c) 2006 IPCC Guidelines for National Greenhouse Gas Inventories. Volume 4: Agriculture, Forestry and Other Land Use. IGES, Japan

IPCC (2019a) 2019 Refinement to the 2006 IPCC Guidelines for National Greenhouse Gas Inventories. Chapter 5:Cropland. Calvo Buendia, E., Tanabe, K., Kranjc, A., Baasansuren, J., Fukuda, M., Ngarize S., Osako, A., Pyrozhenko, Y., Shermanau, P. and Federici, S.(eds). Published: IPCC, Switzerland.

IPCC (2019b) 2019 Refinement to the 2006 IPCC Guidelines for National Greenhouse Gas Inventories. Glossary.

Kätterer T, Bolinder MA, Andrén O, Kirchmann H, Menichetti L (2011) Roots contribute more to refractory soil organic matter than aboveground crop residues, as revealed by a long-term field experiment. Agric Ecosyst Environ 141:184-192. https://doi.org/10.1016/j.agee. 2011.02.029

Kay S, Rega C, Moreno G, den Herder M, Palma JHN et al (2019) Agroforestry creates carbon sinks whilst enhancing the environment in agricultural landscapes in Europe. Land Use Policy 83:581-593. https://doi.org/10.1016/j.landusepol.2019.02.025

Kühne S, Enzian S, Jüttersonke B, Freier B, Forster R et al (2000) Beschaffenheit und Funktion von Saumstrukturen in der Bundesrepublik Deutschland und ihre Berücksichtigung im Zulassungsverfahren im Hinblick auf die Schonung von Nichtzielarthropoden. Mitteilungen aus der Biologischen Bundesanstalt für Land- und Forstwirtschaft Berlin-Dahlem 378

Kürsten E (2000) Fuelwood production in agroforestry systems for sustainable land use and CO2-mitigation. Ecol Eng 16:69-72. https:// doi.org/10.1016/S0925-8574(00)00054-9

Lal R (2004) Soil carbon sequestration to mitigate climate change. Geoderma 123:1-22. https://doi.org/10.1016/j.geoderma.2004.01. 032

Lal R (2008) Carbon sequestration. Philos Trans R Soc 363:815-830. https://doi.org/10.1098/rstb.2007.2185

Lingner S, Thiessen E, Hartung E (2018) Aboveground biomass estimation in linear forest objects: 2D- vs. 3D-data. J For Sci 64:523-532. https://doi.org/10.17221/106/2018-jfs

Lorenz K, Lal R (2014) Soil organic carbon sequestration in agroforestry systems. A review Agronomy for Sustainable Development 34: 443-454. https://doi.org/10.1007/s13593-014-0212-y

Lotfi A, Javelle A, Baudry J, Burel F (2010) Interdisciplinary analysis of hedgerow network landscapes' sustainability. Landsc Res 35:415426. https://doi.org/10.1080/01426397.2010.486857

Ma Z, Chen HYH, Bork EW, Carlyle CN, Chang SX, Fortin J (2020) Carbon accumulation in agroforestry systems is affected by tree species diversity, age and regional climate: a global meta-analysis. Glob Ecol Biogeogr 29:1817-1828. https://doi.org/10.1111/geb. 13145

Mayrinck RC, Laroque CP, Amichev BY, Van Rees K (2019) Aboveand below-ground carbon sequestration in shelterbelt trees in Canada: a review. Forests 10. https://doi.org/10.3390/f10100922

Minasny B, Malone BP, McBratney AB, Angers DA, Arrouays D et al (2017) Soil carbon 4 per mille. Geoderma 292:59-86. https://doi. org/10.1016/j.geoderma.2017.01.002

Moher D, Liberati A, Tetzlaff J, Altman DG, Group P (2009) Preferred reporting items for systematic reviews and meta-analyses: the PRISMA statement. PLoS Med 6:e1000097. https://doi.org/10. 1371/journal.pmed.1000097

Mokany K, Raison RJ, Prokushkin AS (2006) Critical analysis of root : shoot ratios in terrestrial biomes. Glob Chang Biol 12:84-96. https:// doi.org/10.1111/j.1365-2486.2005.001043.x

Monokrousos N, Papatheodorou EM, Diamantopoulos JD, Stamou GP (2006) Soil quality variables in organically and conventionally cultivated field sites. Soil Biol Biochem 38:1282-1289. https://doi.org/ 10.1016/j.soilbio.2005.09.023
Montagini F, Nair PKR (2004) Carbon sequestration: an underexploited environmental benefit of agroforestry systems. Agrofor Syst 61: 281-295. https://doi.org/10.1023/B:AGFO.0000029005.92691.79

Mulia R, Dupraz C (2006) Unusual fine root distributions of two deciduous tree species in southern France: what consequences for modelling of tree root dynamics? Plant Soil 281:71-85. https://doi.org/10. 1007/s11104-005-3770-6

Nair PKR (2012) Carbon sequestration studies in agroforestry systems: a reality-check. Agrofor Syst 86:243-253. https://doi.org/10.1007/ s10457-011-9434-Z

Nair PKR, Kumar BM, Nair VD (2009) Agroforestry as a strategy for carbon sequestration. J Plant Nutr Soil Sci 172:10-23. https://doi. org/10.1002/jpln.200800030

Odyssee-Mure (2020) Odyssee indicators database. https://www. indicators.odyssee-mure.eu/. Accessed 26/05 2020

Oelbermann M, Voroney RP, Kass DCL, Schlönvoigt AM (2005) Above- and below-ground carbon inputs in 19-, 10- and 4-yearold Costa Rican Alley cropping systems. Agric Ecosyst Environ 105:163-172. https://doi.org/10.1016/j.agee.2004.04.006

Pandey DN (2002) Carbon sequestration in agroforestry systems. Clim Pol 2:367-377. https://doi.org/10.3763/cpol.2002.0240

Paulsen HM, Bauer B (2008) Soil organic carbon stocks in hedge-banks as agricultural marginal areas. Ressortforschung für den ökologischen Landbau:73-80

Poeplau C, Don A (2013) Sensitivity of soil organic carbon stocks and fractions to different land-use changes across Europe. Geoderma 192:189-201. https://doi.org/10.1016/j.geoderma.2012.08.003

Poeplau C, Don A, Vesterdal L, Leifeld J, Van Wesemael BAS et al (2011) Temporal dynamics of soil organic carbon after land-use change in the temperate zone - carbon response functions as a model approach. Glob Chang Biol 17:2415-2427. https://doi.org/10.1111/ j.1365-2486.2011.02408.x

Poschlod P, Braun-Reichert R (2017) Small natural features with large ecological roles in ancient agricultural landscapes of Central Europe - history, value, status, and conservation. Biol Conserv 211:60-68. https://doi.org/10.1016/j.biocon.2016.12.016

R Core Team (2019) R: a language and environment for statistical computing. R Foundation for Statistical Computing, Vienna, Austria

Rasse DP, Rumpel C, Dignac M-F (2005) Is soil carbon mostly root carbon? Mechanisms for a specific stabilisation. Plant Soil 269: 341-356. https://doi.org/10.1007/s11104-004-0907-y

Regulation (EU) No 1306/2013 (2013) Regulation (EU) No 1306/2013 OF THE EUROPEAN PARLIAMENT AND OF THE COUNCIL of 17 December 2013 on the financing, management and monitoring of the common agricultural policy and repealing Council Regulations (EEC) No 352/78, (EC) No $165 / 94$, (EC) No 2799/98, (EC) No 814/2000, (EC) No 1290/2005 and (EC) No 485/2008.

Robertson H, Marshall D, Slingsby E, Newman G (eds) (2012) Economic, biodiversity, resource protection and social values of orchards: a study of six orchards by the Herefordshire Orchards Community Evaluation Project. Natural England Commissioned Report Number 90,

Rohatgi A (2019) WebPlotDigitalizer. Web based tool to extract data from plots, images, and maps. Version 4.2. https://automeris.io/ WebPlotDigitizer Accessed 09/12 2019

Schlamadinger B, Bird N, Johns T, Brown S, Canadell J et al (2007) A synopsis of land use, land-use change and forestry (LULUCF) under the Kyoto Protocol and Marrakech Accords. Environ Sci Pol 10: 271-282. https://doi.org/10.1016/j.envsci.2006.11.002

Schlesinger WH, Bernhardt ES (2013) Biogeochemistry, an analysis of global change. 3rd edition edn. Elsevier, Oxford

Schoeneberger MM (2008) Agroforestry: working trees for sequestering carbon on agricultural lands. Agrofor Syst 75:27-37. https://doi.org/ $10.1007 / \mathrm{s} 10457-008-9123-8$ 
Seidel D, Busch G, Krause B, Bade C, Fessel C, Kleinn C (2015) Quantification of biomass production potentials from trees outside forests - a case study from central Germany. BioEnergy Research 8: 1344-1351. https://doi.org/10.1007/s12155-015-9596-Z

Sierra J, Nygren P (2005) Role of root inputs from a dinitrogen-fixing tree in soil carbon and nitrogen sequestration in a tropical agroforestry system. Aust J Soil Res 43. https://doi.org/10.1071/sr04167

Thiel B, Smukler SM, Krzic M, Gergel S, Terpsma C (2015) Using hedgerow biodiversity to enhance the carbon storage of farmland in the Fraser River delta of British Columbia. J Soil Water Conserv 70:247-256. https://doi.org/10.2489/jswc.70.4.247

Van Vooren L, Reubens B, Broekx S, De Frenne P, Nelissen V et al (2017) Ecosystem service delivery of agri-environment measures: a synthesis for hedgerows and grass strips on arable land. Agric Ecosyst Environ 244:32-51. https://doi.org/10.1016/j.agee.2017. 04.015

Van Vooren L, Reubens B, Ampoorter E, Broekx S, Pardon P et al (2018) Monitoring the impact of hedgerows and grass strips on the performance of multiple ecosystem service indicators. Environ Manag 62: 241-259. https://doi.org/10.1007/s00267-018-1043-4

Vashum KT, Jayakumar S (2012) Methods to estimate above-ground biomass and carbon stock in natural forests - a review. Journal of Ecosystem \& Ecography 02. https://doi.org/10.4172/2157-7625. 1000116

Viechtbauer W (2010) Conducting meta-analyses in R with the metafor package. J Stat Softw 36:1-48. https://doi.org/10.18637/jss.v036. i03
Walter C, Merot P, Layer B, Dutin G (2003) The effect of hedgerows on soil organic carbon storage in hillslopes. Soil Use Manag 19:201207. https://doi.org/10.1111/j.1475-2743.2003.tb00305.x

Weber HE (2008) Gebüsche, Hecken, Krautsäume. Ökosysteme Mitteleuropas aus geobotanischer Sicht. Verlag Eugen Ulmer GmbH \& Co., Stuttgart; Hohenheim

Wellbrock N, Grüneberg E, Riedel T, Polley H (2017) Carbon stocks in tree biomass and soils of German forests. Central European Forestry Journal 63:105-112. https://doi.org/10.1515/forj-2017-13

Welsch J, Hale RJ, Buckley HL, Case BS (2016) Quantification and comparison of shelterbelt carbon stocks within and between an organic mixed-cropping farm and a conventional dairy farm. New Zealand Natural Sciences 41:14-28. https://doi.org/10.26021/458

Wiesmeier M, Lungu M, Cerbari V, Boincean B, Hübner R et al (2018) Rebuilding soil carbon in degraded steppe soils of Eastern Europe: the importance of windbreaks and improved cropland management. Land Degrad Dev 29:875-883. https://doi.org/10.1002/ldr.2902

Wolf C, Klein D, Weber-Blaschke G, Richter K (2016) Systematic review and meta-analysis of life cycle assessments for wood energy services. J Ind Ecol 20:743-763. https://doi.org/10.1111/jiec.12321

Wolton R (2012) Managing UK hedges for firewood: is this practical, economic and environmentally acceptable? In: Dover JW (ed) Hedgerow Futures, Staffordshire University. Stoke-on-Trent, UK

Publisher's note Springer Nature remains neutral with regard to jurisdictional claims in published maps and institutional affiliations. 